\title{
Pediatric Immunization Practice During Coronavirus Disease-2019 Pandemic
}

\author{
Riska Habriel Ruslie ${ }^{1 *}$, Darmadi Darmadi ${ }^{2}$, Gontar Alamsyah Siregar ${ }^{2}$ \\ ${ }^{1}$ Department of Child Health, Faculty of Medicine, Universitas Prima Indonesia, Medan, North Sumatera, Indonesia; \\ ${ }^{2}$ Department of Internal Medicine, Faculty of Medicine, Universitas Sumatera Utara, Haji Adam Malik General Hospital, Medan, \\ North Sumatera, Indonesia
}

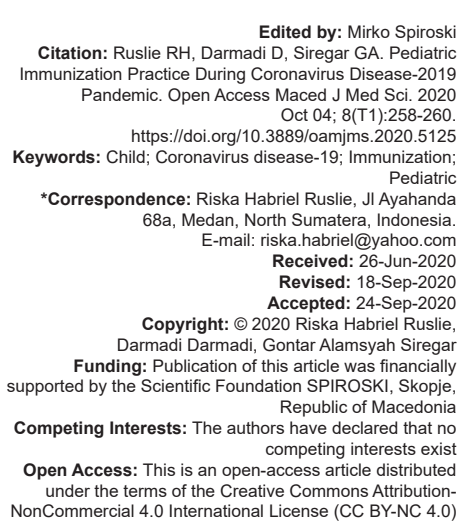
Edited by: Mirko Spirosk
Citation: Ruslie RH, Darmadi D, Siregar GA. Pediatric Immunization Practice During Coronavirus Disease-2019 Pandemic. Open Access Maced J Med Sci. 2020 Oct 04; 8(T1):258-260.
https://doi.org/10.3889/oamims 2020.5125 Keywords: Child; Coronavirus disease-19; Immunization; *Correspondence: Riska Habriel Ruslie, Jl Ayahanda $68 \mathrm{a}$, Medan, North Sumatera, Indonesia. E-mail: riska.habriel@yahoo.com Received: 26-Jun-2020 Revised: $18-\mathrm{Sep}-2020$ Accepted: 24-Sep-202 Copyright: ๑ 2020 Riska Habriel Ruslie Darmadi Darmadi, Gontar Alamsyah Siregar Funding: Publication of this article was financially supported by the Scientific Foundation SPIROSKI, Skopje, Competing Interests: The authors have declared that no competing interests exist

Open Access: This is an open-access article distributed under the terms of the Creative Commons AttributionNonCommercial 4.0 International License (CC BY-NC 4.0)

\begin{abstract}
At the end of 2019, coronavirus disease-2019 (COVID-19) started to spread worldwide and caused a pandemic in March 2020. Epidemiologic data of COVID-19 in the pediatric population are not certain. The pandemic also decreases routine immunization coverage in children which lead to increased risk of vaccine-preventable disease outbreak. Routine immunization practice should be continued with due regard to health protocol. Children in contact with COVID-19 patients or children who previously have COVID-19 may be immunized after 14 days of symptomfree or confirmed negative by two polymerase chain reaction tests at a minimum interval of $24 \mathrm{~h}$. Bacillus CalmetteGuerin, influenza, and pneumococcal immunization give a positive effect on COVID-19. Until present, there is no available vaccine for COVID-19.
\end{abstract}

\section{Introduction}

In December 2019, a cluster of patients in contact with a market in Wuhan, Hubei Province, China, was hospitalized due to pneumonia with unknown etiology [1], [2]. Further, investigations confirmed that the disease was caused by a virus named severe acute respiratory syndrome-coronavirus-2 (SARS-CoV-2), and the disease was named as CoV disease-2019 (COVID19) [3]. In March 2020, the disease had spread to Europe, and on March 11, 2020, the World Health Organization (WHO) declared COVID-19 as a pandemic [1], [2]. Children, health-care staffs, and elderly population are at a higher risk for SARS-CoV-2 infection [1]. Unfortunately, screening for COVID-19 is less frequently done in the pediatric population due to asymptomatic disease course in this population, giving uncertain epidemiological data regarding the disease [2], [3]. Children are less affected by COVID-19 compared to adults, with only about $2 \%$ of total cases in China and $1.2 \%$ in Italy [3], [4]. There was no evidence regarding vertical transmission from mother to child [1], [2], [3]. However, antibody toward SARS-CoV-2 was detected in newborns from mothers with COVID-19 [3].
The most common clinical manifestations of COVID-19 in children are fever (51.6\%), cough (47.3\%), and sore throat (17.9\%) [2], [3]. Extra-respiratory symptoms commonly found are diarrhea (9.7\%), vomiting (7.2\%), and fatigue (10.6\%) [3], [4]. The realtime polymerase chain reaction from the nasopharyngeal swab is considered as the gold standard for diagnosing COVID-19. At present, there is no specific treatment for COVID-19. Broad-spectrum antiviral and antibiotics are utilized. Corticosteroid and intravenous immunoglobulin (lg) are given for children with severe cases [1], [3]. The estimated mortality for children with COVID-19 from a systematic review was $0.08 \%$ [3].

A vaccine against COVID-19 is considered as the most important and powerful weapon to fight the disease. Unfortunately, until the present, there is no effective vaccine which has been discovered [2]. During this pandemic, many countries urge shelter-in-place or stay-at-home policy. This policy, in addition to parental anxiety regarding COVID-19 transmission to their children, extremely decreased routine immunization coverage. This condition increases the risk of vaccinepreventable disease outbreak during or after COVID-19 pandemic [5]. Data from the Ministry of Health Republic of Indonesia showed that $84 \%$ of primary health facilities 
stopped or postponed immunization practice. National immunization coverage was also decreased during COVID-19 pandemic, with a range between $0.5 \%$ and $87 \%$ [6]. We aimed to describe pediatric immunization during COVID-19 pandemic and to discuss about the effects of routine immunization both in reducing vaccinepreventable diseases and modulate COVID-19.

\section{Pediatric Immunization During COVID-19 Pandemic}

Immunization is one of the most important inventions in the medical world. It greatly reduces morbidity and mortality from several diseases, such as smallpox, tuberculosis, and polio [7], [8]. Routine immunization must be conducted to prevent vaccine-preventable diseases outbreak even in COVID-19 pandemic [7], [9], [10]. Prevention of vaccine-preventable diseases outbreak gives huge advantages during this pandemic, such as saving lives and saving resources [7], [10]. Immunization practice may also be used to spread messages regarding COVID-19 prevention and to identify early signs and symptoms of COVID-19 [10]. Parents or proxy should be informed about the importance of completion of routine immunization because if an outbreak occurred, we will face a double burden: COVID-19 pandemic and vaccinepreventable disease outbreak [6].

Immunization practice in children should follow health protocol for decreasing the risk of exposure to subjects with COVID-19 [9], [10]. Before bringing children for immunization, parent and proxy are suggested to make an appointment. This is important to avoid overcrowded rooms [7]. The crowded situation should be minimized by limiting the number of adult who accompanies the child [10]. Children's companions should be screened for fever and other COVID-19 symptoms [7]. The area for immunization practice should be well ventilated and frequently disinfected [7], [10]. The area should be spacious enough with airflow from health personnel to children. Entrance and exit doors should be separated [7]. The separation between well and sick visits, by modifying clinic structure, rescheduling visits, and physical spacing, is important. Younger infants are prioritized to receive immunizations [5], [7], [9], [10]. All health-care personnel should use complete personal protective equipments and practice hand hygiene as often as possible [7], [10]. In a situation of personal protective equipment shortage, health-care personnel should minimally wear the medical mask and fresh gloves for each child. Children should wait for 30 min after immunization in a separated place to monitor vaccine-associated adverse reaction [7].

Children in contact with COVID-19 patients or suspected for COVID-19 may still receive routine immunizationsincethereisnoevidenceofcontraindications reported. However, they should be free from symptoms for 14 days or preferably tested negative for COVID-19 in two consecutive samplings within $24 \mathrm{~h}$ interval before immunization [7], [10]. Catch-up immunization should also be continued during this pandemic with similar health protocol with routine immunization [5], [7], [10]. Mobile immunization facility may be optimized to deliver the vaccine to children in remote areas or children who missed their vaccination schedule [7]. School-based immunization is still applicable if conducted with proper health protocol [5], [10].

At present, there is no specific vaccine against COVID-19 [10]. Influenza immunization is suggested during COVID-19 pandemic. The reason is to lower the probability of having influenza which has similar symptoms with COVID-19. By receiving influenza immunization, health-care personnel may at least exclude influenza as the etiology of respiratory symptoms [9]. Passive immunization, using polyclonal and monoclonal antibodies, is being investigated for COVID-19 while waiting for the vaccine. Passive immunization is a process of administering mature antibodies to treat infectious diseases. It can occur naturally or artificially. The antibody may be obtained from the serum of immunized animals or convalescent humans. However, harvesting antibodies require a very high cost. $\lg Y$ is one of the several candidates for COVID-19 passive immunization. IgY is produced by birds, reptiles, and amphibians, but its function is similar to IgG in mammals. IgY has been used in immunization against several microorganisms such as Salmonella $\mathrm{sp}$. and rotavirus. Continuous investigations are being held to obtain SARS-CoV-2 specific IgY [11].

\section{The Role of Immunization in COVID-19}

Bacillus Calmette-Guerin (BCG) vaccination is reported to be correlated with the incidence and outcome of COVID-19. BCG vaccination decreases the incidence and alleviates the outcome of COVID-19 in countries which adopt mandatory BCG vaccination program [4], [8], [12], [13]. A study reported that countries which apply universal BCG immunization had a significantly lower incidence and mortality rates compared to those who do not apply universal BCG vaccination program [13]. Furthermore, BCG strain also affects its protective effect against COVID-19. Countries with early strains BCG (Japan and Russia) show a lower incidence of COVID-19 compared to countries with late strains (Denmark). On the other hand, the protective effect of BCG vaccination is affected by other factors, as reported by data from Finland and Australia. Both countries reported low mortality rates from COVID-19 even they had stopped BCG vaccination in their regions [12]. Some factors which affect this result are national disease burden, the difference in testing rate, isolation policy, and demographic parameter [8]. 
The protective effect of BCG is possible because $B C G$ vaccination is reported to be able to elicit protection against other pathogens through sustained changes in the innate and adaptive immune systems. BCG induces histone modifications and epigenetic reprogramming of interleukin (IL)-1, IL-6, and tumor necrosis factor (TNF). This results in known as "trained immunity" [4], [8], [12], [13]. The concept of trained immunity was introduced in 2011. According to the concept, bacterial infection induces crossprotection against other pathogens. Unfortunately, this cross-protection is temporary and quickly disappeared. However, memory lymphocytes triggered by the infection may also provide longer-term cross-protection [4]. In vivo studies have confirmed this effect against avian influenza A and yellow fever viruses [8].

Vaccines may also contain immune adjuvant which promotes innate immune function. Influenza vaccination is hypothesized to have a protective effect against SARS-CoV-2 since the S-glycoprotein of SARS-CoV-2 has similarities with the hemagglutinin antigen glycoprotein in the influenza virus. Pneumococcal conjugate and polysaccharide vaccines are also suspected to have an advantage in preventing bacterial coinfection in COVID-19 children. Investigations regarding the effect of available immunization on COVID-19 are being conducted [4]. The WHO has not approved the utilization of any vaccine for COVID-19 management until valid evidence becomes available [8]. The authors did not find any study or report regarding the contribution of other vaccines in the incidence and outcome of patients with COVID-19.

\section{Conclusion}

Routine pediatric immunization practice during COVID-19 pandemic must be carried out while still applying standard health protocol. Children in contact with COVID-19 patients or previously have that COVID-19 should be immunized 14 days after the symptom diminished or after COVID-19 showed a negative result. BCG, influenza, and pneumococcal immunization give particular positive effects on COVID-19. Until present, there is no specific vaccine for COVID-19.

\section{References}

1. Rothan HA, Byrareddy SN. The epidemiology and pathogenesis of cronavirus disease (COVID-19) outbreak. J Autoimmun. 2020;109:102433. https://doi.org/10.1016/j.jaut.2020.102433
PMid:32113704

2. Jeng M. Coronavirus disease 2019 in children: Current status. $J$ Chin Med Assoc. 2020;83(6):527-33. https://dx.doi.org/10.1097 \%2FJCMA.0000000000000323.

PMid:32502117

3. Liguoro I, Pilotto C, Bonanni M, Ferrari ME, Pusiol A, Nocerino A, et al. SARS-COV-2 infection in children and newborns: A systematic review. Eur J Pediatr. 2020;18:1-18. https://dx.doi. org/10.1007\%2Fs00431-020-03684-7.

PMid:32424745

4. Lyu J, Miao T, Dong J, Cao R, Li Y, Chen Q. Reflection on lower rates of COVID-19 in children: Does childhood immunizations offer unexpected protection? Med Hypotheses. 2020;143:109842. https://doi.org/10.1016/j.mehy.2020.109842. PMid:32425304

5. Santoli JM, Lindley MC, DeSilva MB, Kharbanda EO, Daley MF, Galloway L, et al. Effects of the COVID-19 pandemic on routine pediatric vaccine ordering and administration United States, 2020. Morb Mortal Wkly Rep. 2020;69:591-3. http://dx.doi. org/10.15585/mmwr.mm6919e2.

PMid:32407298

6. Direktorat Jenderal Pencegahan dan Pengendalian Penyakit. Buletin Surveilans PD3I and Imunisasi. Jakarta: Kementerian Kesehatan Republik Indonesia; 2020. Available from: https://www.who.int/docs/default-source/searo/indonesia/ sit-rep/buletin-surveilans-pd3i-dan-imunisasi-edisi-2-2020. pdf?sfvrsn=2a76da54_2. [Last accessed on 2020 May 01].

7. Direktorat Surveilans dan Karantina Kesehatan. Petunjuk Teknis Pelayanan Imunisasi Pada Masa Pandemi COVID-19. Jakarta: Kementerian Kesehatan Republik Indonesia; 2020. p. 11-37. Available from: https://www.covid19.kemkes.go.id/ protokol-covid-19/petunjuk-teknis-pelayanan-imunisasi-padamasa-pandemi-covid-19/\#.X2QYUVQzblU. [Last accessed on 2020 May 12]

8. O'Connor E, The J, Kamat AM, Lawrentschuk N Bacillus Calmette Guerin (BCG) vaccination use in the fight against COVID-19 what's old is new again? Future Oncol. 2020;16(19):1323-5. https://dx.doi. org/10.2217\%2Ffon-2020-0381

PMid:32406253

9. American Association of Pediatrics Illinois Chapter Immunization and COVID-19 Fact Sheet. Elk Grove Village: American Academy of Pediatrics; 2020. Available from: https:// www. illinoisaap.org/wp-content/uploads/2020/03/ICAAPCOVID-19-FAQ-Sheet-1.pdf. [Last accessed on 2020 May 11].

10. World Health Organization. Immunization in the Context of COVID-19 Pandemic: Frequently Asked Questions. Geneva: World Health Organization; 2020. Available from: https:// www.apps.who.int/iris/handle/10665/331818?show=full. [Last accessed on 2020 May 11]

11. Constantin C, Neagu M, Supeanu TD, Chiurciu V, Spandidos . IgY turning the page toward passive immunization in COVID-19 infection (review). Exp Ther Med. 2020;20:151-8. https://doi. org/10.3892/etm.2020.8704 PMid:32536989

12. Miyasaka M. Is BCG vaccination cusally related to reduced COVID-19 mortality? EMBO Mol Med. 2020;12:e12661. https:// doi.org/10.15252/emmm.202012661 PMid:32379923

13. Roy S. Does the Bacillus Calmette-Guerin vaccine provide protection from COVID-19? Indian J Med Sci. 2020;72:17-20. https://dx.doi.org/10.25259\%2FIJMS_37_2020 